\title{
Relative yield-per-recruit and management strategies for Cynoscion acoupa (Perciformes: Sciaenidae) in Lake Maracaibo, Venezuela
}

\author{
Orlando José Ferrer Montaño ${ }^{1 *} \&$ Isabel Cristina Morales ${ }^{1}$ \\ 1. Departamento de Biología, Facultad Experimental de Ciencias, Universidad del Zulia, Maracaibo, estado Zulia, \\ Venezuela; carichuano@hotmail.com, the_footprint@hotmail.com \\ * Corresponding author
}

Received 10-I-2012. C Corrected 18-VII-2012. Accepted 20-VIII-2012.

\begin{abstract}
Acoupa weakfish, Cynoscion acoupa, in Lake Maracaibo is subject to intense commercial fishing by an artisanal fleet, and a recent decrease in fish size observed from landings is of concern. This fishery has not yet been modeled, and its assessment and the establishment of management practices to overcome the current overfished condition are urgently needed. To address this, we used recent and past empirical growth estimates to model relative yield-per-recruit under different lengths at first capture. Our results from relative yield-perrecruit analysis showed evidence that growth and recruitment overfishing occur under current fishing practices in Lake Maracaibo. Particular attention was given to fishing practices in El Tablazo Bay where young, small fish predominate in the commercial catches (mean total length $=33.7 \mathrm{~cm}$ ), well below the length at first sexual maturity $(\sim 40 \mathrm{~cm} T L)$ for both sexes. As management strategies, we propose to set a mesh size limit at or above $8.89 \mathrm{~cm}$ (3.5in), which will reduce fishing mortality of immature fish, increase yield-per-recruit, and will result in an increase of Acoupa weakfish recruitment for the long term in Lake Maracaibo. Rev. Biol. Trop. 61 (1): 173-180. Epub 2013 March 01.
\end{abstract}

Key words: Cynoscion acoupa, relative yield-per-recruit, length at first maturity, Lake Maracaibo, Venezuela.

All Lake Maracaibo fishing is carried out on a small scale, scattered, and without defined landing points (de Espinosa 1972), making it particularly difficult to manage, given the difficulties to obtain reliable catch statistics. Therefore, Lake Maracaibo fishing is prone to overfishing of target stocks. It is essential for all those who work in Lake Maracaibo fisheries to understand the structure and dynamics, and the effects of fishing on fish stocks for the proper definition of sustainable harvest strategies, without which the fisheries of Lake Maracaibo would be condemned to collapse (Pauly et al. 2002).

Acoupa weakfish Cynoscion acoupa (Lacepède 1801) is the most abundant and economically important species of the family Sciaenidae in Lake Maracaibo. It supports a large artisanal fishery, which has been operating in
Lake Maracaibo for many years, with annual landings reaching 18000 metric tons in the 1960s and 1970s (Ferrer Montaño 1995). Sciaenids are well known for their croaking or drumming sounds emitted during the spawning season (Mok et al. 2009). Lake Maracaibo fishers have given it the name of tambor (drum), and the sound it produces tronío (thunder), to the tissue or muscle attached to the abdominal wall that produces the characteristic noise emitted by Acoupa weakfish during the spawning activity (de Espinosa 1972). Fishers in Lake Maracaibo take advantage of this noise to set their gillnets targeting both mature males and females Acoupa weakfish specimens. Local fishers call this fishing method pesca de tronío (de Espinosa 1972).

There are evidences indicating growth and recruitment overfishing for Acoupa weakfish 
in Lake Maracaibo in as much as catches have decreased sharply in the last few years, and only small and mid-size individuals are landed (Morales 2009). Since mid 1980s, annual catch of Acoupa weakfish has remained constant at levels of 4000tons (Morales 2009, Goncalves 1986). Also, local fishers have indicated that now just few sexually mature individuals are caught in the pesca de tronío (Morales 2009), indicating that the spawning aggregations have diminished sharply. In addition to the deleterious effects of the pesca de tronío, fisheries in Lake Maracaibo operate under an open access regime with monofilament nylon gillnets ranging 2-5in stretch mesh sizes.

Obviously, active management to reduce fishing pressures on mature individuals in the spawning grounds has become an urgent matter. Although several reports (de Espinosa 1972, Goncalves 1986, Ferrer Montaño 1995, Morales 2009) have documented the necessity to regulate Acoupa weakfish fisheries, no legal actions have been taken yet, precluding the rational management of the fishery resource. Yield-per-recruit can provide the benchmarks to assess overfishing growth (Gulland 1983, King 1995, Jones \& Wells 2001). Specifically, yield-per-recruit modeling provides reference points to theoretically maximize yield from a cohort or increase the number of large fish in the population. In 1957, Beverton \& Holt (1957) developed an age-structured theory of fishing. Then, in 1966, these same authors (Beverton \& Holt 1966) developed a lengthstructured version of their yield-per-recruit model ideally suited for use in data-sparse, tropical setups, and since then it has been called the relative yield-per-recruit ( $\left.\mathrm{Y}^{\prime} / \mathrm{R}\right)$ model. Since its publication, the length-structured Y'/R model has been applied widely, notably in the tropics, and has constituted the base for a number of useful generalizations in fishery management (Pauly \& Soriano 1986).

However, as important as this modeling is to science-based management, no published application of yield-per-recruit models exists for Acoupa weakfish from Lake Maracaibo. In our study we used an empirical modeling approach to evaluate from a historic point of view the effect of fishing mortality and age at first capture on $Y^{\prime} / R$ models of Acoupa weakfish. Pertinent data gathered from papers by de Espinosa (1972), Ferrer Montaño (unpublished data), and Morales (2009) were compiled and analyzed to generate models predicting $Y^{\prime} / R$ under diverse management scenarios. These models were used to determine whether regulations such as size limits and effort regulations are necessary to manage the Lake Maracaibo Acoupa weakfish fishery.

\section{MATERIALS AND METHODS}

Lake Maracaibo $\left(8^{\circ} 22^{\prime}-11^{\circ} 51^{\prime} \mathrm{N}\right.$ and $70^{\circ} 30^{\prime}-73^{\circ} 24^{\prime} \mathrm{W}$ ) is a coupled ocean-lake system connected through a partially mixed estuary, located on the Caribbean coast of Venezuela (Antoranz et al. 2001). The whole Lake Maracaibo system is a complex of several interacting bodies of water: Gulf of Venezuela, El Tablazo Bay, Maracaibo Strait, the Lake itself and many streams and rivers. A navigational channel reaching depths of $18 \mathrm{~m}$ crosses the system from the Gulf to the Lake. There is an extensive mangrove system in the Northern part of the Lake and a substantial fluvial input in the Southern part. The rain regime has a pronounced peak during the second half of the year. At that time most of the Lake exhibits freshwater conditions caused by rain runoff. The surface water salinity throughout the Lake fluctuates strongly. Samplings were conducted in El Tablazo Bay, and near the sampling area salinity generally ranges 10 -28UPS and temperature ranges $26-30^{\circ} \mathrm{C}$. The study area has a maximum depth of $12 \mathrm{~m}$ at mean low water and its substrates are primarily fine sand and mud.

All the specimens used in this study were recorded from commercial artisanal fishery from landing points in Sabaneta de Palmas and Punta de Palmas, two small towns located in El Tablazo Bay. These towns have been traditional landing sites for the artisanal fishery fleet and most studies on the fishery of Acoupa weakfish in Lake Maracaibo have obtained samples from 
there. The fishery in these sites targets stocks of Acoupa weakfish residing in El Tablazo Bay fishing grounds. All fish recorded were caught with gillnets. As we mentioned, we focus in this paper on data reported in several sources to generate $Y^{\prime} / R$ curves. Below, we briefly describe the parameter estimation procedures employed by the above mentioned sources.

Data from de Espinosa (1972) came from analyzing growth rings in scales. All fish recorded by de Espinosa were caught either with gillnets or with hook-and-line between May 1969-December 1970. Gillnets used to fish Acoupa weakfish were made with a 3.55.0in mesh. The hook-and-line fishery generally used a number eight hook, with fresh bait consisting of Gobioides broussonetti and, occasionally, shrimp; de Espinosa collected most of his samples in landing sites and supplemented it with others obtained directly by experimental fishing.

For determining and interpreting age groups from growth rings, de Espinosa (1972) used a lineal regression analysis using the least squares method. The Walford method (Walford 1946) was used for estimating the von Bertalanffy growth function (VBGF) parameters. Age frequencies were converted to frequency percentages and plotted against ages to estimate the instantaneous total mortality rate (Z; /year) applying linear regression analysis on points above full recruitment.

Data from Morales (2009) came from two sources: 1) unpublished data collected weekly by the senior author of this paper (OJFM) between May 1985-April 1986 and 2) her own data set collected weekly between February-July 2009. All fish recorded by OJFM and Morales (2009) were caught with gillnets 2.5-5.0 inches mesh. Both sets of data were analyzed following the same protocol. All fish were measured for total length (TL; cm). Samples were pooled by month and given a single mid-month date. Bias associated with size selectivity of gill nets was corrected by using mesh selectivity curves developed from lengthgirth relationships for Acoupa weakfish in Lake Maracaibo by Ferrer Montaño (1995). Length frequency data were analyzed with FISAT II to estimate growth parameters of the VBGF and $Z$. The length converted catch curve (Ricker 1975, Pauly 1984) was used for estimating Z A regression line was fitted to the descending limb from the modal group plus one through all ages represented by at least five individuals. Natural mortality (M; per year) was estimated using Pauly's (Pauly 1980) equation: LnM=$0.0152-0.279 \operatorname{Ln}\left(\mathrm{L}_{\infty}\right)+0.6543 \mathrm{Ln}(\mathrm{K})+0.463 \mathrm{Ln}$ (T), where $\mathrm{Ln}=$ natural logarithm, $\mathrm{M}=$ natural mortality rate, $\mathrm{L}_{\infty}=$ von Bertalanffy's asymptotic length, $\mathrm{K}=$ von Bertalanffy's growth coefficient and $\mathrm{T}=$ mean water temperature $\left({ }^{\circ} \mathrm{C}\right)$ for the sampling area. All water temperature values used in the analyses were measured by Ferrer Montaño (1995) with an YSI model 57 oxygen meter. Fishing mortality (F; per year) was estimated from $\mathrm{Z}=\mathrm{F}+\mathrm{M}$. For a better description of the fishing methods used in the area of study, refer to de Espinosa (1972).

Data generated by all above mentioned sources were used as input parameters for estimation of $\mathrm{Y}^{\prime} / \mathrm{R}$ using the method of Beverton \& Holt (1966), which is defined by

$\mathrm{Y}^{\prime} / \mathrm{R}=\mathrm{EU}^{\mathrm{M} / \mathrm{K}}\left[1-(3 \mathrm{U} /(1+\mathrm{m}))+\left(3 \mathrm{U}^{2} /(1+2 \mathrm{~m})\right)-(\mathrm{U} 3 /(1+3 \mathrm{~m}))\right]$

where

$\mathrm{m}=(1-\mathrm{E}) /(\mathrm{M} / \mathrm{K})=\mathrm{K} / \mathrm{Z}$

$\mathrm{U}=1-\left(\mathrm{L}_{\mathrm{c}} / \mathrm{L}_{\infty}\right)$ (the fraction of growth to be completed after entry into the exploited phase), and $\mathrm{E}=\mathrm{F} / \mathrm{Z}$ (the exploitation rate or the fraction of deaths caused by fishing).

$\mathrm{M}=$ instantaneous natural mortality coefficient

$\mathrm{K}=$ von Bertalanffy growth parameter

$\mathrm{Z}=$ instantaneous total mortality coefficient

$\mathrm{L}_{\mathrm{c}}=$ mean length at first capture

$\mathrm{L}_{\infty}=$ asymptotic length

$\mathrm{F}=$ instantaneous fishing mortality coefficient

Relative yield-per-recruit can be calculated for given input values of $\mathrm{M} / \mathrm{K}, \mathrm{L}_{\infty}$ and $\mathrm{L}_{\mathrm{c}}$ for values of $\mathrm{E}$ ranging $0-1$, corresponding to $\mathrm{F}$ values ranging $0-\infty$. The plot of $Y^{\prime} / R$ against $\mathrm{F}$ gives a curve with a maximum value, $\mathrm{F}_{\mathrm{MSY}}$, for a given value of $\mathrm{L}_{c}$. Thus, when $\mathrm{L}_{\mathrm{c}}, \mathrm{F}$ and $\mathrm{M} / \mathrm{K}$ are known for a certain fishery, the 
actual fishing mortality can be compared with the $\mathrm{F}_{\mathrm{MSY}}$ level and management measures be proposed as necessary.

Computations of $Y^{\prime} / R$ were performed in Microsoft Excel. We used a sensitivity analysis procedure to deal with the problem of uncertainty involved in the stock assessment (Pauly 1980). This analysis consisted of investigating the effect of variations in $\mathrm{L}_{\mathrm{c}}$ in the results of $Y^{\prime} / R$. In sensitivity analysis different assumptions regarding parameter values or inclusion of different data sets are run and results are compared (Hilborn 2003). Most of the values used in the analyses were direct estimates from the authors reported; however, $\mathrm{L}_{\mathrm{c}}$ was unknown for this fishery and we decided to set it to the length at first sexual maturity reported by de Espinosa (1972) and Ferrer Montaño (1995). Restricting captures to the length at first maturity is a commonly used management tool. Ferrer Montaño (1995) indicated that restriction of captures to the length at first maturity will ensure that fish have spawned at least once before being harvested. The length at first maturity reported by Ferrer Montaño (1995) was $38.1 \mathrm{~cm}$ TL for males and $40 \mathrm{~cm}$ TL for females, whereas de Espinosa (1972) reported $37 \mathrm{~cm}$ TL for both sexes. To cover a wide range of options given the uncertainty around these values, we set $\mathrm{L}_{\mathrm{c}}$ to range $30-50 \mathrm{~cm}$ TL.

\section{RESULTS}

The length range obtained by Morales (2009) was $26.3-48.8 \mathrm{~cm}$ TL (mean $\mathrm{TL} \pm \mathrm{SD}=33.7 \pm 7.57 \mathrm{~cm}$ TL; modal group $=31 \mathrm{~cm}$ $\mathrm{TL}$; $\mathrm{SD}=$ standard deviation), contrasting sharply with the ranges obtained by OJFM $(31-95 \mathrm{~cm}$ $\mathrm{TL}$; mean $\mathrm{TL} \pm \mathrm{SD}=48.7 \pm 4.1 \mathrm{~cm}$ TL; modal group $=45 \mathrm{~cm}$ TL) and de Espinosa (1972) $(22.5-97.5 \mathrm{~cm}$ TL; mean $\mathrm{TL} \pm \mathrm{SD}=49 \pm 3.9 \mathrm{~cm}$ $\mathrm{TL}$; modal group $=40 \mathrm{~cm}$ TL). The von Bertalanffy growth function obtained by Morales (2009) was $\mathrm{L}_{\mathrm{t}}=80\left(1-\mathrm{e}^{-0.26 t}\right)$, whereas the obtained by OJFM was $\mathrm{L}_{\mathrm{t}}=98.1\left(1-\mathrm{e}^{-0.26 \mathrm{t}}\right)$ and the reported by de Espinosa (1972) was $\mathrm{L}_{\mathrm{t}}=105.5\left(1-\mathrm{e}^{-0.27(\mathrm{t}-0.21)}\right)$.

Parameters used in the simulations are summarized in table 1. Our simulations indicated that $\mathrm{F}_{\mathrm{MSY}}$ for the fishery of Acoupa weakfish from Lake Maracaibo under the different scenarios studied ranged 0.7-0.9/year for data from de Espinosa (1972) (Fig. 1A, Table 1), from 0.7-1.1/year for data from OJFM (Fig. 1B, Table 1) and from 0.8-2.0/year for data from Morales (2009) (Fig. 1C, Table 1). Relative yield-per-recruit curves showed marked peaks only at the lowest values of $\mathrm{L}_{c}$ (30 and $40 \mathrm{~cm} \mathrm{TL}$ ); otherwise, curves were asymptotic. Although relative yield-per-recruit for de Espinosa (1972) and OJFM indicated that levels of $\mathrm{F}$ were slightly below that for the maximum potential yield-per-recruit (Fig. 1A,

TABLE 1

Parameter values used in relative yield-per-recruit simulations for Acoupa weakfish Cynoscion acoupa

\begin{tabular}{lccccccc} 
& $\mathrm{L}_{\infty}$ & $\mathrm{K}$ & $\mathrm{L}_{\mathrm{c}}$ & $\mathrm{Z}$ & $\mathrm{M}$ & $\mathrm{F}$ & $* * * * \mathrm{~F}_{\mathrm{MSY}}$ \\
de Espinosa (1972) & 105.5 & 0.27 & $* * 37$ & 1.17 & $* 0.53$ & 0.64 & $0.7-0.9$ \\
Ferrer Montaño & 98.1 & 0.26 & $* * * 38.1 / 40$ & 1.23 & 0.53 & 0.70 & $0.7-1.1$ \\
Morales (2009) & 80 & 0.26 & - & 3.76 & 0.56 & 3.20 & $0.8-2.0$ \\
\hline
\end{tabular}

$\mathrm{L}_{\infty}=$ asymptotic total length $(\mathrm{cm}), \mathrm{K}=$ von Bertalanffy growth parameter(/year), $\mathrm{L}_{\mathrm{c}}=$ mean length at first capture (cm), $\mathrm{Z}=$ instantaneous total mortality coefficient(/year), $\mathrm{M}=$ instantaneous natural mortality coefficient (/year), $\mathrm{F}=$ instantaneous fishing mortality coefficient (/year), $\mathrm{F}_{\mathrm{MSY}}=$ instantaneous fishing mortality coefficient (/year) at maximum sustainable yield. *M for de Espinosa (1972) was estimated using Pauly's (Pauly 1980) equation assuming a mean water temperature of $28^{\circ} \mathrm{C}$. $* * \mathrm{~L}_{\mathrm{c}}$ reported by de Espinosa (1972) corresponding to the length at first sexual maturity for both sexes. $* * * \mathrm{~L}_{\mathrm{c}}$ reported by Ferrer Montaño (1995) corresponding to the length at first sexual maturity for males (38.1 cm TL) and female (40 cm TL). $* * * *$ Range of $\mathrm{F}_{\mathrm{MSY}}$ values as given for $\mathrm{L}_{\mathrm{c}}$ used in simulations $(30-50 \mathrm{~cm} \mathrm{TL})$. 


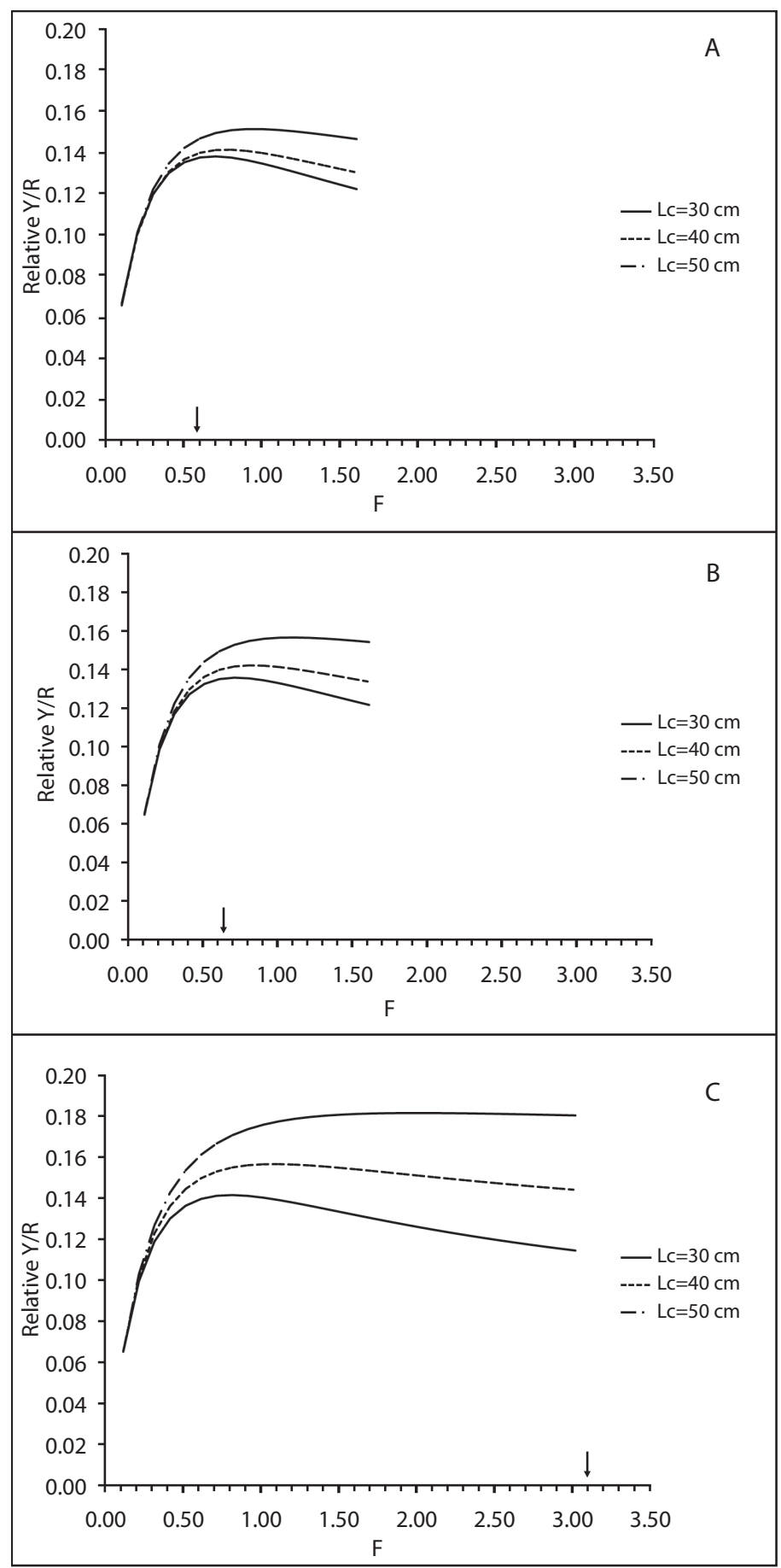

Fig. 1. Beverton \& Holt relative yield-per-recruit curves on fishing mortality (F) for Acoupa weakfish Cynoscion acoupa from Lake Maracaibo as a function of several mean length at first capture $\left(\mathrm{L}_{\mathrm{c}}\right)$. (A) Data from de Espinosa (1972), (B) data from Ferrer Montaño (Morales 2009), and (C) data from Morales (2009). The arrow on each section indicates de F exerted on the fishery for the time data were obtained. 
1B, Table 1), estimates for Morales (2009) indicated that current $\mathrm{F}$ was well beyond that for the maximum potential yield-per-recruit (Fig. 1C, Table 1).

\section{DISCUSSION}

Whenever age determination is difficult, or a long series of catch and effort data is unavailable, models based on yield-per-recruit offer a valuable alternative (Holden 1995, Peixer et al. 2007). Holden (1995) suggests that yield per recruit curves offer a simple and clear way for managers involved in fisheries to take decisions regarding, for example, the advantages of reducing mortality rates and/or increasing the minimum age of recruitment for fisheries. Our results indicate that the current $Y^{\prime} / R$ for Acoupa weakfish in Lake Maracaibo is well below its maximum for all values of $\mathrm{L}_{\mathrm{c}}$ used in our simulations. The only way yield-per-recruit and economic efficiency could be maximized for Acoupa weakfish in Lake Maracaibo would be to increase $\mathrm{L}_{\mathrm{c}}$ to values well beyond current ones, along with a sharp decreasing of $\mathrm{F}$.

Our results suggest growth overfishing (fish harvested before they have achieved maximum yield-per-recruit) and recruitment overfishing (spawning stock reduced to a level that precludes adequate production of young fish) (Gulland 1983) is limiting fishery yield and commercial value of Acoupa weakfish, whether $\mathrm{L}_{\mathrm{c}}$ is high or low. Heavy fishing is directed to young Acoupa weakfish in Lake Maracaibo. Our simulations clearly indicate the importance of limiting fishing mortality in regions where young fish occur.

Prior to 2009, Acoupa weakfish landed in the study site averaged $49 \mathrm{~cm}$ TL (de Espinosa 1972, Morales 2009), and over $42 \%$ of the catch was $40 \mathrm{~cm}$ TL or smaller, raising the potential of growth overfishing at that time. Capture at this small length also raises concern for recruitment overfishing, because Acoupa weakfish attain its first sexual maturity at lengths $\sim 40 \mathrm{~cm}$ TL. The potential for recruitment overfishing is minimal in areas outside the El Tablazo Bay (for instance, the Southern portion of the Gulf of Venezuela), where the fishery targets larger fish that have reproduced for many years before being captured. Currently, on the other hand, growth overfishing and recruitment overfishing have exacerbated, with over $90 \%$ of the catch below $40 \mathrm{~cm}$ TL (Morales 2009). All this prompt for management regulations.

With the exception of blue crab (Callinectes sapidus) fishery, which operates under a closed season (August-September) management strategy, there is no fishery regulation for Lake Maracaibo fisheries; in other words, fisheries in Lake Maracaibo operate under an open access regime. We consider this point to be of paramount importance, because the available information suggests that with continuation of the current trends in the fisheries, there is a high risk of Acoupa weakfish stock collapsing. The aim of commercial fisheries management should be to ensure sustainability while optimizing benefits. The long-term persistence of a fishery depends upon maintaining the productivity capacity of the stocks being exploited. No stakeholder's objectives can be achieved by extirpating the resource (Hilborn 2008).

Yield is not sustainable when fish are harvested before they are allowed to spawn at least once, and when fishing greatly reduces population size (Miranda et al. 2000). By comparing the length at first maturity with the length at first capture we may obtain a rough idea of whether yield estimates are sustainable. Any exploited stock is more likely to be sustained if the average length of fish in the harvest is larger than the average length at maturity. Thus, the average individual harvested has had a chance to spawn at least once.

No doubt that our analyses are based on limited data. However, they represent the best data currently available for Acoupa weakfish. One of the general principles of the Code of Conduct for Responsible Fishing is that "States and subregional and regional fisheries management organizations should apply a precautionary approach widely to conservation, management and exploitation of living aquatic resources... taking account of the best 
scientific evidence available" (FAO 1995). The Code further states "That the absence of adequate scientific information should not be used as a reason for postponing or failing to take measures to conserve target species, associated or dependent species and non-target species..." (FAO 1995).

It is in the light of this general principle that we present the available information on Acoupa weakfish, and indicate how that information can guide management until better information becomes available. Even with the uncertainties in the input parameters, in particular natural mortality, our analysis clearly indicates that $Y^{\prime} / R$ is a useful basis for a management reference point that can be used by fishery managers in Lake Maracaibo. Despite these limitations, several generalizations could be made to diagnose the direction the fishery will take given major harvest modifications.

Gillnet fisheries have the advantage that they provide the opportunity to regulate meshsize and allocate exploitation to segments of fish stocks. Such rationing can be manipulated to balance welfare of the fish stock and societal profits (Miranda et al. 2000). Acoupa weakfish reach a marketable size long before the age (length) of first maturity. Therefore, any shift in the fishery towards larger fish could result in significant stock improvement. Thus, a minimum size limit may be appropriate. This minimum size limit could be reached setting a mesh size limit at or above $8.89 \mathrm{~cm}$ (3.5in). This will increase the number of spawners in future years. The mesh size limit will reduce fishing mortality of immature fish, increase yield-per-recruit, and result in an increase in recruitment of Acoupa weakfish in Lake Maracaibo (Ferrer Montaño 1995). An alternative would be to limit fishing in areas (El Tablazo Bay) and times where small fishes are abundant. However, the distribution of Acoupa weakfish at various stages in its life history is not sufficiently well known for this approach to be implemented.

Limited knowledge on landings, the lack of good indices of abundance, and the biological characteristics of Acoupa weakfish warrant a precautionary approach to establish any management targets (Caddy \& Mahon 1995). Acoupa weakfish exhibit relatively high interannual and intraannual variability in abundance (de Espinosa 1972, Morales 2009). There are not information regarding the relationship between stock and recruitment, and regarding environmental effects on Acoupa weakfish recruitment. All this suggests that reducing Acoupa weakfish abundance could result in increased variability in recruitment, and could increase the risk that there may be several consecutive years of low abundance and even stock collapsing.

\section{ACKNOWLEDGMENTS}

This study was partially funded by Universidad del Zulia, Maracaibo through the Division of Sectorial Basic Studies from the Experimental Faculty of Science. We deeply appreciate many fishers who provided access to their boats and helped us with field collections. We recognize the pioneering efforts of the late Victor de Espinosa to opening the door to the Acoupa weakfish investigation in Lake Maracaibo.

\section{RESUMEN}

La curvina, Cynoscion acoupa, en el Lago de Maracaibo se encuentra sometida a una intensa actividad pesquera comercial. No obstante, antes de este estudio no se había examinado el potencial efecto de la sobrepesca a través del modelado. Utilizamos estimados empíricos de crecimiento actuales y pasados para modelar el rendimiento-por-recluta relativo bajo diferentes longitudes de primera captura. Presentamos evidencia a partir de resultados de rendimiento-por-recluta relativo que indica que existe sobrepesca por crecimiento y reclutamiento bajo las prácticas pesqueras actuales en el Lago de Maracaibo. Se puso particular atención a las pesquerías en la Bahía El Tablazo donde predominan peces jóvenes pequeños en las capturas (longitud total promedio $=33.7 \mathrm{~cm}$ ), muy por debajo de la longitud de primera madurez sexual $(\sim 40 \mathrm{~cm}$ LT) para ambos sexos. Proponemos establecer un tamaño de malla igual o superior a $8.89 \mathrm{~cm}(3.5 \mathrm{in})$, el cual reduciría la mortalidad por pesca de peces inmaduros, aumentaría el rendimiento-por-recluta y a largo plazo aumentaría el reclutamiento de la curvina en el Lago de Maracaibo. 
Palabras clave: Cynoscion acoupa, rendimiento-porrecluta relativo, longitud de primera madurez, Lago de Maracaibo, Venezuela.

\section{REFERENCES}

Antoranz, A.M., J.L. Pelegri \& P. Masciángoli. 2001. Tidal currents and mixing in the Lake Maracaibo estuarine system. Sci. Mar. 65 (Suppl. 1): 155-166.

Beverton, R.J.H. \& S.J. Holt. 1957. On the dynamics of exploited fish population. U.K. Ministry of Agriculture and Fisheries, Fisheries Investigations (Series 2), London, United Kingdom.

Beverton, R.J.H. \& S.J. Holt. 1966. Manual of methods for fish stock assessment. Part 2. Tables of yield functions. FAO Fish. Tech. Paper (38) Rev. 1, Rome, Italy.

Caddy, J.F. \& R. Mahon. 1995. Reference points for fisheries Management. FAO Fish. Tech. Paper 347.

De Espinosa, V. 1972. La biología y pesca de la curvina Cynoscion maracaiboensis, del Lago de Maracaibo. Series Recursos y Explotación Pesqueros 2(3), Caracas, Venezuela.

Ferrer Montaño, O.J. 1995. Selectivity of gillnets for lake curvina, Cynoscion acoupa, in Lake Maracaibo, Zulia state, Venezuela. B. Mar. Sci. 56: 68-75.

Food and Agriculture Organization of the United Nations. 1995. Code of conduct for responsible fisheries. FAO, Rome, Italy.

Goncalves, O.M. 1986. La pesca de la curvina. FONAIAP Divulga No. 21, Caracas, Venezuela.

Gulland, J.A. 1983. Fish stock assessment: a manual of basic methods. FAO/Wiley series on food and agriculture, Vol. 1. Wiley, New York, New York, USA.

Hilborn, R. 2003. The state of the art in stock assessment: where we are and where we are going. Sci. Mar. 67(Suppl. 1): 15-20.

Hilborn, R. 2008. Knowledge on how to achieve sustainable fisheries, p. 45-56. In K. Tsukamoto, T. Kawamura, T. Takeuchi, T.D. Beard \& M.J. Kaiser (eds.). Fisheries for global welfare and environment, $5^{\text {th }}$ World Fisheries Congress 2008, Yokohama, Japan.

Holden, M. 1995. Beverton and Holt revisited. Fish. Res. 24: 3-8.
Jones, C.M. \& B.K. Wells. 2001. Yield-per-recruit analysis for black drum, Pogonias cromis, along the East coast of the United States and management strategies for Chesapeake Bay. Fish. B-NOAA 99: 328-337.

King, M. 1995. Fisheries biology, assessment and management. Fishing News Books, Blackwell, Cambridge, Massachusetts, USA.

Miranda, L.E., A.A. Agostinho \& L.C. Gomes. 2000. Appraisal of the selective properties of gill nets and implications for yield and value of the fisheries at tha Itaipu Reservoir, Brazil-Paraguay. Fish. Res. 45: 105-116.

Mok, H.K., H.Y. Yu, J.P. Ueng \& R.C. Wei. 2009. Characterization of sounds of the blackspotted croaker Protonibea diacanthus (Sciaenidae) and localization of its spawning sites in estuarine coastal waters of Taiwan. Zool. Stud. 48: 325-333.

Morales, I. 2009. Crecimiento y mortalidad de la curvina Cynoscion acoupa del lago de Maracaibo. Trabajo Especial de Grado, Universidad del Zulia, Maracaibo, Zulia, Venezuela.

Pauly, D. 1980. On the inter-relationships between natural mortality, growth performance and mean environmental temperature in 175 fish stocks. J. Cons. CIEM. 39: 175-192.

Pauly, D. 1984. Length-converted catch curves. A powerful tool for fisheries research in the tropics. ICLARM Fishbyte 2: 17-19.

Pauly, D. \& M.L. Soriano. 1986. Some practical extensions to Beverton and Holt's relative yield-per-recruit model, p. 491-495. In J.L. Maclean, L.B. Dizon \& L.V. Hosillos (eds.). The first Asian fisheries forum. Asian Fisheries Society, Manila, Philippines.

Pauly, D., V. Christensen, S. Guénette, T.J. Pitcher, U.R. Sumaila, C.J. Walters, R. Watson \& D. Zeller. 2002. Towards sustainability of world fisheries. Nature 418: 689-695.

Peixer, J., A.C. Catella \& M. Petrere Júnior. 2007. Yield per recruit of the pacu Piaractus mesopotamicus (Holmberg, 1887) in the pantanal of Mato Grosso do Sul, Brazil. Braz. J. Biol. 67: 561-567.

Ricker, W.E. 1975. Computation and interpretation of biological statistics of fish populations. B. Fish. Res. Board Can. 191.

Walford, L.A. 1946. A new graphic method of describing the growth of animals. Biol. Bull. 90: 141-147. 